ARTICLE

DOI: $10.1057 /$ s41599-018-0120-x

\title{
Regional politics of an urban age: Can Europe's former industrial cities create a new industrial economy to combat climate change and social unravelling?
}

Anne Power ${ }^{1}$

\begin{abstract}
Across Europe, cities are struggling to cope with the loss of industrial jobs; decay of urban infrastructure; in-migration (most often from poorer regions); outward sprawl pressures; traffic congestion and transport bottlenecks. The environmental consequences of continuing urban development are deeply threatening to the survival of both city and countryside. Growing anti-immigrant sentiments, sluggish growth and intense inequality provoke a level of disaffection and marginalisation that threaten social cohesion, with highly divisive consequences. This article, based on a ten year study of seven European cities, argues that recovery is under way in ex-industrial cities with major reinvestment from national and European funds. Transformative deals and innovations have created new jobs and led to population regrowth after years of decline. There are hopeful signs that in different parts of Europe-North, South, East and West-a new phase of growth in core cities is emerging, based on university-civic business partnerships; reuse and remodelling of existing, devalued infrastructure; reinvestment and expansion of rail and water networks; the growth in advanced manufacturing; reduced energy use and the spread of renewable energy; innovative research and technology; city centre and neighbourhood restoration and integration. Europe's former industrial cities are part of much bigger metropolitan areas or city regions and some benefits are spreading out from core cities to more peripheral areas, although this is often swamped by poverty and unemployment, skills mismatch and inadequate reinvestment. A complex patchwork of changes is driven by a new kind of city leadership; growing collaboration between the core and periphery of cities; central government and Europe-wide concern both to devolve more powers and reduce dependence on central funds; regional devolution and metropolitan level programmes-particularly in areas of skills, research and development, infrastructure, and umbrella services backed with cash and political enthusiasm. Cities are recovering across the world's most urban continent by combining reuse and new inventions, which deliver more sustainable economies.
\end{abstract}

\footnotetext{
${ }^{1}$ London School of Economics, London, UK. Correspondence and requests for materials should be addressed to A.P. (email: Anne.Power@lse.ac.uk)
} 


\section{Introduction}

urope is the world's most urban continent. Not only did its diverse people become majority urban before any other major continent; it also industrialised earlier, became richer, colonised further afield, and fought more and bloodier wars than any other continent (Times Books, 1990). Britain is an extreme case. It became overwhelmingly urban before any other European country (Halsey, 1988; Briggs, 1983). It was the first to industrialise and it grew on the back of extensive trial and error that created widespread damage to Britain's social and environmental conditions but also generated innovative urban management (Briggs, 1968). This model of growth spread rapidly across Europe and America.

If we look across different European countries at cities that became powerful and wealthy through their industry, we see patterns of economic growth and environmental exploitation, social progress and extreme hardship, intense wealth creation and dire poverty, followed by rapid decline, severe population and job losses, high unemployment, deep decay, and loss of purpose. This pattern is repeated right across Europe (Power et al. 2008).

Many assumptions have been made about the causes and consequences of the collapse of industry, and loss of rationale in many declining industrial regions of Europe where major industries disappeared. Northern England is a stark illustration as two centuries of intense industrial development created a gap between Northern and Southern England (Osbourne, 2014). The vote to leave the European Union in 2016 reflected this gap (Goodwin and Heath, 2016).

This pattern is also visible in France's former industrial regions where the Front National-an extreme nationalist party-made significant headway among disillusioned ex-industrial workers running on a xenophobic campaign (Fabrique de la Cité, 2015). In Eastern Europe, including Eastern Germany, industrial collapse, major population exodus and contrasting incomes with more prosperous Western Germany have led to extreme politics emerging and a general level of disillusion that provides a seedbed for future problems (The Economist, 2017).

The basic theory underpinning this article is in two parts:

- When city economies grow through industrial-scale extraction of non-renewable fossil fuels and raw materials, and turn them into mass produced, machine-made goods that pollute air, water and soil over a large surrounding area, those economies will exhaust their natural resources and decline, leaving lasting environmental, social and economic damage in the cities themselves, surrounding regions and national economies.

- Former industrial cities that respond by adopting low impact methods of recovery, restoring environments, and reusing resources, including human resources, can regenerate their economies, strengthen their social conditions and reinstate valuable infrastructure, thus leading to lower impact growth.

We call these cities "weak market cities" because they struggle economically having lost their traditional large industries. The common rhetoric that parades their poverty and low wage economies as proof of their poor prospects, fails to observe signs of regrowth (Power et al. 2010). This article argues that former industrial cities have indeed caused extreme environmental damage but they are so vital to Europe's future that governments invest in reversing the damage to ensure their survival. This article poses a key question with two related questions:

- Is the recovery and regrowth of former industrial cities in Europe sustainable?
- Will the regrowth benefit the peripheries of the cities, which grew rapidly in the industrial heyday?

- Will the lessons from these former industrial cities spread to other cities across Europe?

\section{Methods}

We investigated seven case study cities across Europe intensively over a long-term period, using primary research methods: evidence from European Union, national and local sources; frequent research visits to all the cities; communication in local languages to ensure depth and clarity; verifying local, direct evidence using wider statistical evidence.

The seven cities were selected based on the following criteria:

- They were leaders in industrial growth and prosperity in their city-regions and nationally;

- They experienced severe industrial decline, closures of major industries, job and population losses since the 1970s;

- Their city-leaders, both private and public, took significant initiatives towards recovery;

- The cities gained support from national governments and the European Union;

- The cities showed signs that recovery was happening, even where problems still dominated.

External investment was significant in helping the cities to round the corner, but local innovations in policy and practise were as important. We carried out detailed case study research in each city in order to establish patterns of development.

Many of Europe's former industrial cities matched the five criteria we used to select our case studies. There were at least eight core cities in the UK with similar conditions, and similar numbers in the other European countries. The European Union's Urban Audit provided invaluable baseline evidence in 2007 that has since been updated (European Commission, 2007-). It allowed us to identify a wide range of cities. The particular case studies for each country were selected with advice from the European Regional Development Division and from academic experts in each country, on the basis that they reflected wider trends in city decline, and because they were subject to measurable recovery efforts.

Our research has covered the period from when ex-industrial cities were at a turning point to when they demonstrated measurable signs of regrowth. Two of the cities, Belfast and SaintÉtienne, only showed such clear signs of recovery in population and jobs by around 2011. Many Eastern European ex-industrial cities, which we did not include because of their very different context and history, are still struggling, as are many American cities with similar historic roles (Power et al. 2010).

The seven former industrial cities covered Britain, Northern Ireland, France, Germany, Spain and Italy: Sheffield, Belfast, Lille, Saint-Étienne, Leipzig, Bilbao, and Torino. Several cities from each country qualified. Local and national experts argued that these were representative "archetypes" of "weak market cities" (City Reformers Group, 2006). These cities displayed more resilience and more capacity for recovery than was foreseen in the period of steepest decline. They all stopped losing population in the early $21^{\text {st }}$ century and grew jobs through new enterprises that encouraged people to move in faster than they moved out. Their populations are therefore growing (Power, 2016). Some cities are recovering faster than others; Saint-Étienne and Belfast were the slowest to round the corner to positive re-growth, but even they are now stronger in employment and population than at the point of steepest decline (Insee, 2013; ONS, 2016). 


\section{Box 1: | Understanding the rise, fall and recovery of former industrial cities}

Industrial growth

- Carbon intensive industries-highly polluting waste

- Materials extraction and intense resource use

- Machine inventions/scientific advances

- Mass production-strong population growth, explosive wealth creation

- Skilled workforce-urban expansion out of slums into suburbs

- Growth of schools, hospitals, universities, technical colleges

- Improved conditions for most workers

Industrial depletion

- Ravages of industrial development-"ugly cities"

- Environmental costs-land, water, air polluted

- Social costs-extreme hardship at the bottom

- Housing, income, health

- Concentrated poverty and growing polarisation

- Displacement by machinery and automation

- High immigration to fill "worst" jobs

\section{Collapse}

- Rising labour and materials cost

- Competition from cheaper producers

- Withdrawal of major industries

- State protection fails to stop decline

City reinvestment and recovery

- National governments and EU rescue and reinvestment plans

- Clean up of cities

- City centre restoration and cultural attractions

- Neighbourhood renewal-older, inner and newer, outer areas

- Limits to sprawl-metropolitan agreements

- Creation of new city centre housing

- Ex-industrial infrastructure revalued

City innovation

- Changes in city leadership

- Skills development and training

- Support for SMEs

- Job recruitment and job match

- University research, incubators and private partnerships

- Citizen involvement

Resource limits and regrowth

- Land and waterway reclamation

- Reclamation of industrial infrastructure

- Reuse of old buildings-factories, warehouses

- Revitalising engineering and technical skills

- Rapid expansion in renewable energy and energy saving

Source: Author's visits to seven cities

Ex-industrial cities and reinvestment. On many measures, Europe's former industrial cities are still struggling after 30 or more years of steady decline. The Urban Audit, a Europe-wide study of over 300 European cities argues this, by showing the stark contrasts with faster growing, less industrial, more high-tech cities (Eurostat, 2013; European Commission, 2007). Yet while it is true that Europe's declining industrial areas face a major gap with more "successful" cities, the reversal of population and job losses in their core cities and other signs of recovery which we detail indicate a significant positive trend. This is our core argument (Core Cities Group, 2009).
European governments and the European Union have mounted reinvestment and recovery programmes to reverse urban decline (European Commission, 2015). This major investment in recovery was driven by several factors: Europe's former industrial regions contain large populations that were heavily exploited during Europe's industrial growth era-even significant depopulation has left large populations behind; Europe's cities arouse deep loyalties which can be politically divisive as the recent bout of populism shows, so it is risky to ignore them; the wealth that industrial cities created benefitted whole nations, not just the areas where it was created, so 
shouldering wider responsibility is seen as fair; Europe's bitter wars and aftermath created a sense of solidarity and fairness that has not yet faded (European Community, 1957). All the cities in our study benefitted from this Europe-wide commitment (Fabrique de la Cité, 2013).

European reinvestment requires matching national commitment to tackle the scale of environmental damage that still affects cities today, for example toxic seepage from disused mines around Sheffield and Saint-Étienne. Reclamation of damaged urban environments and old industrial infrastructure was an early step to attract new or expanded uses. This led cities to revalue their obsolete assets including brownfield land, warehouses, factories and plants such as steel furnaces, chemical and gas works, etc. (Urban Task Force, 1999; Fabrique de la Cité, 2013).

Investment targeted heritage buildings, mainly in city centres, including grand town halls, cultural centres, railway stations, canals, dock areas, historic warehouses, etc. Lille, Torino, Bilbao, Belfast and Leipzig illustrate this intense process of heritage reinvestment (Provan, 2016b; Herden and Power, 2016; Power, 2016a; Power, 2016b; Grubb et al. 2016a).

The cities could not preserve their major industries, although several tried, including Sheffield with its miners' headquarters, Bilbao and Torino with violent union clashes, Belfast with decades of sectarian strife and Saint-Étienne with communist-led local governments (City Reports 2007-2016). Their focus shifted to a new economic future and orientated towards generating new opportunities. They saw a continuing loss of manual, industrial jobs being replaced by service jobs; they saw large-scale mass production enterprises substituted by myriad small-scale, locally based enterprises (EIM Business and Policy Research, 2011). City managers initially found it extremely difficult to manage this structural economic transition (Grubb et al. 2016; Provan, 2016a). As jobs grew again, both public and private leaders recognised the significance of small and medium enterprises (SMEs). They formed an increasingly large share of private sector jobs, often inheriting technical skills and a strong external focus from the industrial era (Sheffield City Region, 2014; Winkler, 2007b).

The preoccupation with traditional industries and a defensive reaction to change shifted towards a more open, more partnership-based and more collaborative strategy involving citizens, universities and civic organisations, regional and metropolitan partners, local Chambers of Commerce and government (Parkinson et al. 2006; European Commission, 2007-2016). The citizen focus aimed to overcome the deep bitterness among traditional working classes, which pushed city governments to invest in neighbourhood renewal, community cohesion and community enterprise of many different kinds. This re-orientation encouraged the development of new skills, and training for those willing to shift towards the new economy. Detailed evidence of these changes in policy and practise can be found in the 14 City Reports produced between 2007 and 2016.

In the rest of the article, we explore six areas in more detail:

- What happens to the former industrial workforce and the housing areas where they live, often built specially for industrial workers?

- How does the environmental damage caused by former industrial cities drive environmental innovation?

- Why do small and medium enterprises become the back-bone of the new city economy?

- What happens to metropolitan areas around core cities?

- How solid is regrowth in seven case study cities?

- What is the role of city leadership in city recovery?

First, we propose a framework for understanding the transition from industrial boom to industrial bust, followed by recovery and a new style of growth, showing the causes of decline; the negative consequences; and reinvestment leading to regrowth. Box 1 summarises the main elements in this progression from decline to recovery, under increasing resource constraints. Figure 1 provides an outline framework for this process that underpins our theory: environmental limits curtail industrial city growth when resources become depleted and environments damaged; city recovery depends on the reuse of existing resources and a new kind of growth based on renewable resources, minimal waste, minimal environmental impact, and social integration.

Industrial workforce and working class housing. First, we look at jobs and housing, the restoration of poor neighbourhoods and the challenge of high migrant concentrations.

Jobs. When a whole industrial skill set becomes redundant and hundreds of thousands of jobs vanish in a single city region, as happened in all the cities in this study, then huge dislocations are inevitable (Power et al. 2010). The shock to the labour force of these changes was huge, and the signs of regrowth are only beginning to have an impact in the last decade or so. Loss of specialised jobs makes earlier specialist skills redundant as most manual jobs in heavy industry vanished. It proved hard to retrain manual, industrial workers (usually male) into service workers. Leading sociologists believe that the loss of male breadwinner roles through industrial change directly led to the rise in female headed lone-parent households (Wilson, 1987). The change also affects school which were used to teaching children with a recognised job trajectory, common until the 1980s. The combination of massive jobs losses, family dislocation and youth unemployment created explosive tension in ex-industrial areas (Power and Tunstall, 1997).

The job market was reoriented to soft, rather than hard, skills so that women took many of the new openings. Service jobs in retail, health, social care and administration expanded and women tended to dominate the more social, caring, and service-oriented jobs. They proved more easily adaptable to change, in part because they had not played such a dominant role in older industries, in part driven by the need to close the income gap left by unemployment and a growth in part-time, flexible working (Power et al., 2004).

However, conditions changed once new investment, reclamation and upgrading got underway. City authorities and employers set up special programmes to match the existing but redundant workforce to new jobs and opportunities. A most extraordinary case is the special training programmes that turned released, former para-military prisoners in Belfast into tourist guides for the city's growing urban tourism market (Plöger, 2007d). In Torino, Bilbao, Leipzig and Lille new jobs also emerged in urban tourism, requiring special training and strong local recruitment policies.

Sheffield set up two programmes: "Job Net" to catch young unemployed people wanting a job and training them; and "Job Match" helping new employers find local workers who matched their skills requirements (Winkler, 2007a). Leipzig set up a similar programme (Plöger, 2007b). More recently, jobs have grown in advanced manufacturing, university-led engineering and technical skills. Each specialised technical job, with a narrow highskilled recruitment base, generates up to five related jobs according to studies by the Brookings Institution (Katz and Bradley 2013), and by Sheffield (Sheffield City Region, 2014; Sheffield City Region, 2017). Figure 2 shows how jobs have changed in the seven cities, with a growth in more technical and service jobs and decline in manufacturing - although both Torino and Sheffield have seen some recovery in manufacturing. 

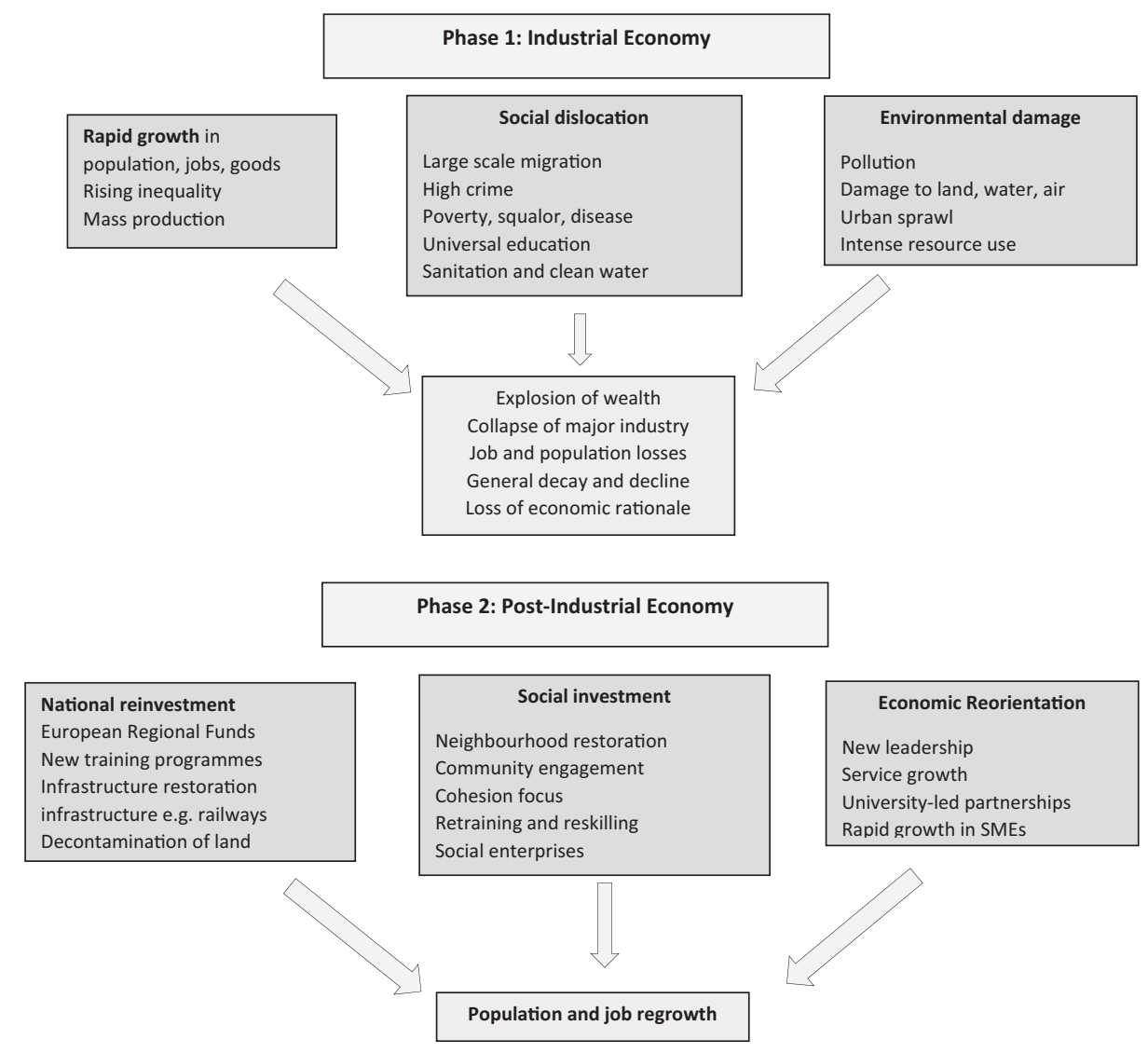

Phase 3: Resource Limited Economy

\begin{tabular}{|l|}
\hline \multicolumn{1}{|c|}{ Depleted Environments } \\
Mining and processing stops \\
Anti-sprawl measures \\
Reuse of existing sites, infrastructure \\
and buildings \\
Strong emphasis on recycling and \\
environmental protection \\
\hline
\end{tabular}
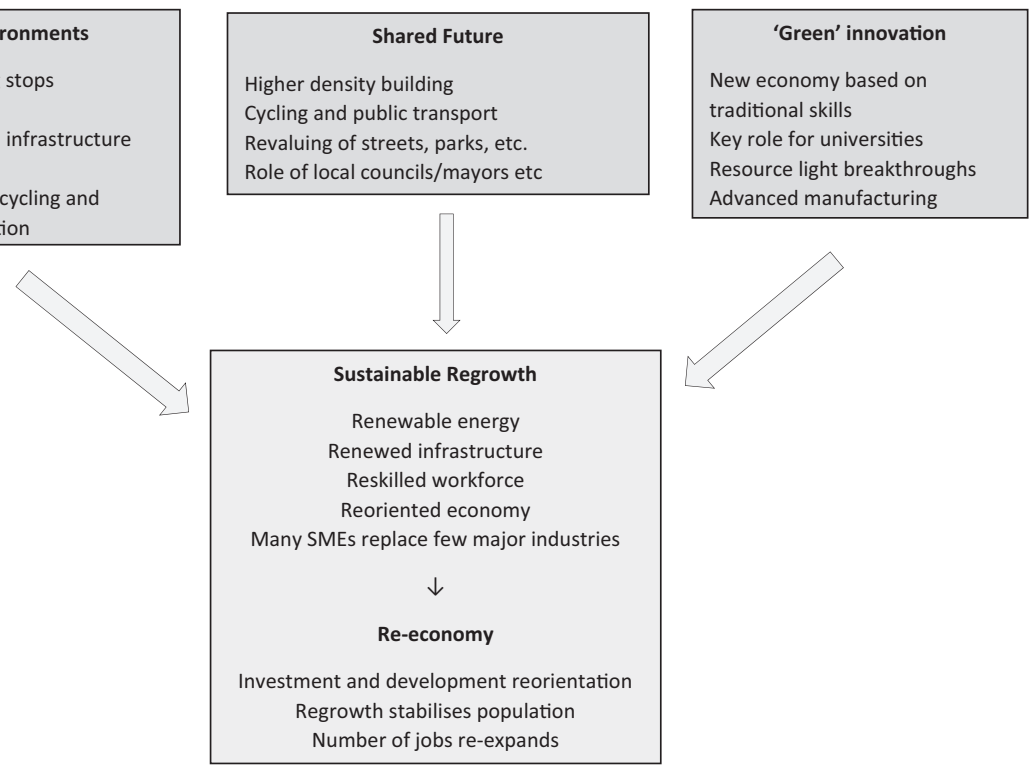

Fig. 1 Outline Framework for understanding former industrial cities' trajectories. The arrows show the direction of change and the factors that influence the three phases of the framework

Inner city neighbourhoods. Inevitably, the older working class areas became poorer, and neighbourhood conditions and services deteriorated as resources drained away from the less desirable neighbourhoods. People moved out of poorer areas as demand fell, making more cheap homes available. Prices stayed low while they rose in more popular regions and, in most of the seven cities, empty property appeared. Some older inner areas, built at the end of the nineteenth and early twentieth century, became almost valueless (Mumford and Power, 2003). Inner Lille, Sheffield, Belfast, Torino, Saint-Étienne, and Leipzig all experienced steep decline. 
Administration and support

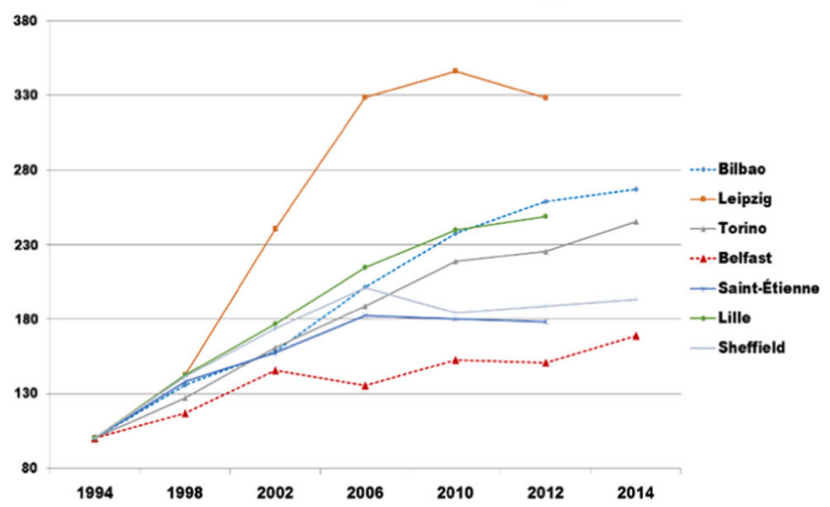

Professional, scientific and technical

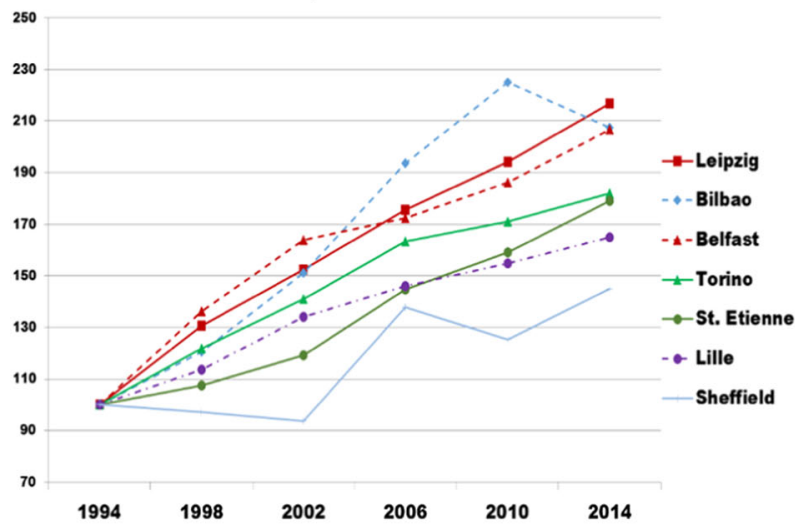

Arts, entertainment and recreation

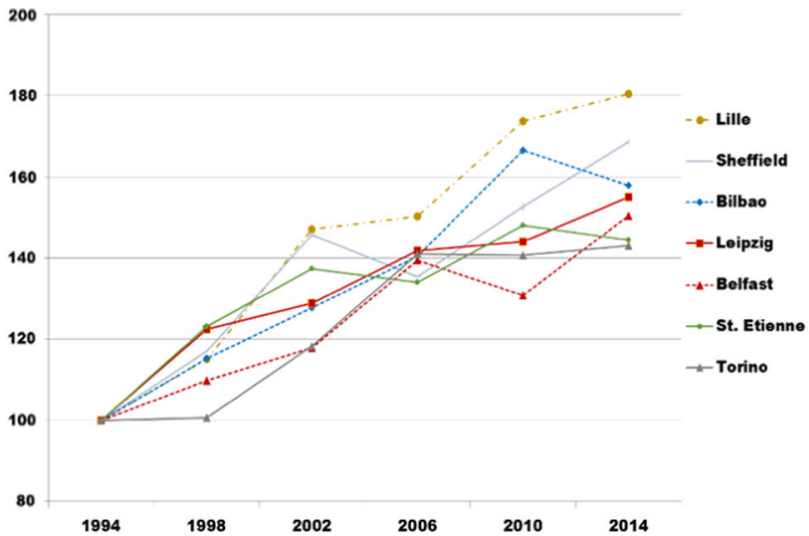

ICT

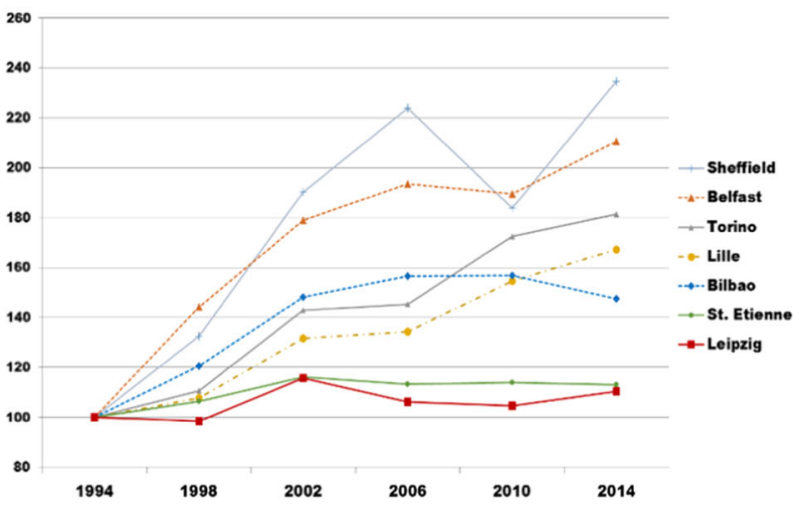

Human Health and Social Work

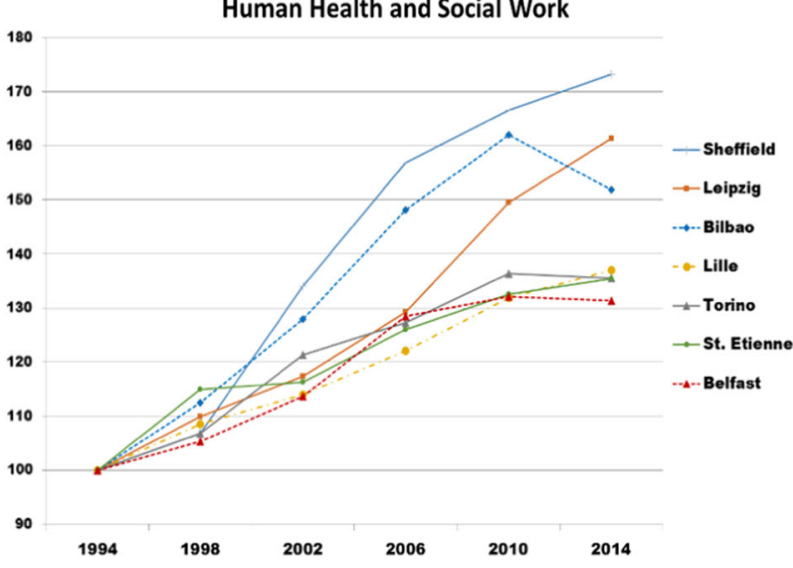

Manufacturing

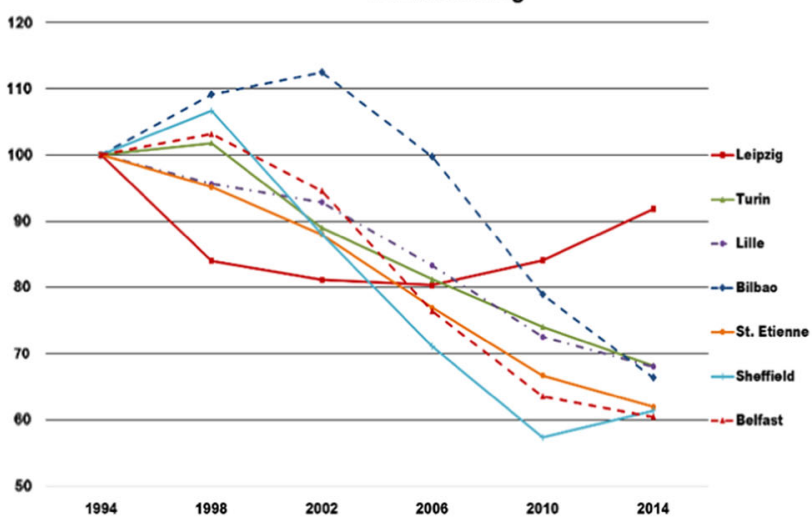

Fig. 2 Changes in employment by sector, 1994-2014. Each of the six parts of Fig. 2 represents a different sector of employment and the trajectory in each city between 1994 and 2014

Inner city population decline was originally triggered by governments during the post-war industrial boom through subsidising the building of mass housing estates on the periphery of cities to improve housing conditions of the industrial workforce. The burst of new, subsidised supply caused inner cities to empty out. This exodus allowed foreign migrants to concentrate in inner areas that were emptying of their traditional working populations. As a result, minority "enclaves" formed within the most run down of the inner areas in all the cities (see below and City Reports).

Leipzig experienced a peculiarly extreme crisis, with tens of thousands of empty homes, mostly in potentially beautiful but severely damaged historic areas of the inner city, following the building of huge outer estates. After reunification in 1989, Leipzig also lost population on its outer estates (Plöger, 2007b). Lille and Saint-Étienne likewise witnessed high levels of abandonment in their historic areas. Their mass housing estates also became poorer and more unpopular (Provan, 2016). Sheffield demolished several, large, modern estates and some older inner city housing too. Cities appeared to be dying.

Minority communities. The movement of immigrant populations and their descendants into the run-down spaces vacated by indigenous residents inevitably increased the conspicuous stigma attached to inner areas. Immigrants were drawn by job opportunities in the post-war boom, and most stayed after the jobs disappeared. All seven cities had inner areas where concentrations of foreign-born residents, distinctive in appearance, language and 
customs, clustered. These so-called "immigrant" areas were invariably the most run down, and from being partially empty, became more crowded and more distinct (Cantle, 2001).

Torino was a particularly striking case as illegal migrants from sub-Saharan Africa and Morocco arrived across the Mediterranean when steep industrial decline in Torino was already far advanced. They crowded into tiny spaces, multi-occupying old, neglected buildings around the city centre, surviving by trading illegally in Torino's central squares. They were tolerated by the city authorities while special programmes attempted to regularise their status (Winkler, 2007b).

In Belfast in the 2000s, as the economy recovered following the Peace Agreement of 1998, thousands of Eastern European migrants and some refugees crossed from Britain to Belfast and secured jobs in hospitality and other growing industries. The level of ethnically motivated attacks on these new migrants grew as divided communities, having already experienced acute job losses, struggled to accommodate and welcome them (The Guardian, 2014; Grubb et al. 2016a).

Integration or gentrification. This complex web of pressures on inner city communities led to a rise in community tensions. In response, programmes to encourage both housing upgrading and social integration were developed. All seven cities ran major upgrading programmes targeting their inner areas. These had a significant impact on physical conditions but ran the risk of displacing existing residents, if low house prices began to rise as improvements took effect. Incomers were attracted by the relatively cheap property and improving conditions. "Urban pioneers" valued the low house prices, ethnic diversity, interesting shops and markets these areas offer (Rogers and Power, 2000). As the process of upgrading spread, inner areas became sought after and too costly for the marginal groups they traditionally housed, but it is a problem most ex-industrial city leaders actively strive for. They want inner areas around the core to thrive again and de facto this is beginning to happen (City Reports, 2016).

Mass housing estates. Large outer estates of concrete high rise blocks, built in the post-war hey-day of mass housing, deteriorated as working populations drifted away. Over the decades since they had been built they became increasingly neglected and difficult to let. As housing demand fell, they housed poorer and poorer tenants (Power, 1999). In the outer estates of Lille and Saint-Étienne by the early 2000s, large, high-rise blocks of hundreds of flats each became occupied almost exclusively by African migrants. In both cities, blocks were demolished because of extreme polarisation, causing riots in Saint-Étienne (Thiolliere, 2007).

City governments were caught between the needs of different ethnic groups, the ambition to restore the popularity of mass estates, and the unmanageable problems of the giant concrete structures. It is an on-going task with new problems emerging as old ones were addressed (Plöger, 2007a; Herden and Power, 2016). Outright demolition is rarely an option as too many residents depend on the large, ready supply of cheap existing housing. Displacement causes many problems, and bitterness lingers in Saint-Étienne's minority community over the demolition of the giant housing block that housed many migrants (Winkler, 2007a; Provan, 2016a). In spite of this, incremental demolition is on-going in Leipzig on its giant peripheral estate, Grünau, with 35,000 units; the same is true in Lille-Sud (Herden and Power, 2016; Provan, 2016).

Reinvestment in estate and neighbourhood renewal over the early 2000s improved conditions sufficiently to attract incomers who liked the areas. By 2012, in every city, there was evidence of higher demand, more economic activity, and more social organisation, growing out of major re-investment to restore conditions in areas with acute social and economic problems. There are still large gaps in both the housing and employment conditions, both within cities as they recover, and between exindustrial cities and other, more successful areas. Nonetheless, from a low baseline, conditions were improving in all the cities, including poor inner and outer city neighbourhoods. Figure 2 summarises these changes (Tables 1 and 2).

Environmental damage. Our second question is how the environmental damage caused by industrial exploitation can lead to environmental innovation.

Scale of damage. The industrial boom and bust posed a fundamental challenge. Land and waterways in and around industrial cities became unusable through industrial pollution and some remains so today. The ground was poisoned with toxic waste; waterways were polluted with industrial effluent; soils, trees and vegetation were lost; factories processed metals, chemicals and other materials that poisoned air, soil and water; coal, gas and petrol burning not only polluted the air but penetrated deep into the soil too. The industrial legacy is long-lasting.

Air pollution from burning fossil fuels not only created major health problems; it also blackened with soot all buildings and even grass, so that everything looked like coal. Air pollution travels hundreds of miles, affecting forests and even causing trees to die back (Walgate, 1983). Pollution problems became so acute that special legislation severely restricted the use of coal in residential areas (HM Government, 1956).

Industry itself grew to a scale previously undreamt of, imposing massive implants in cities. Care was taken in their creation, design and construction, in spite of their soot-blackened appearance. They proved hard to dismantle when redundant. Many simply stayed. Pipes wide enough for a man to walk through; engines so vast that special buildings were built to house them; warehouses, platforms, bridges and lifting machinery filled the landscape of industrial cities and their surroundings, turning these cities into environmental sinks that are not yet fully reclaimed, though full reclamation may be possible. Much of the industrial infrastructure can be restored and reused; giant factories and warehouses are finding new uses often for new enterprises, industries, entertainment and housing.

A dominant legacy of the industrial era are canals, docks and inland waterways. These became drains, carrying poisoned waters down major rivers and into seas. Every leading industrial city was built on a waterway or itself built one as it grew to link heavy industrial goods to markets. Rivers were frequently turned into virtual canals by concreting the sides and bottoms, containing them like prisoners. For example, Leipzig and Sheffield effectively turned their river systems into urban canals. Lille built a canal linking its two rivers (Provan, 2016; Herden and Power, 2016). All these waterways became heavily polluted. Canals, as they fell into disuse for shipping, were gradually turned into tips for every kind of debris. The more disused and neglected they became, the more they were clogged until people had almost forgotten their original function. They became ugly, unusable rubbish dumps, with their natural flow constricted.

Water can be cleaned once the surrounding soils are decontaminated and the poisonous outflows from extraction and industrial by-products are stopped. This happened with the Rhine and Danube, huge river systems almost destroyed by industry (Danube Regional Project, 2001).

Another major devalued legacy of industrial cities was their railway network which had been the nerve centres of trade for these producer cities, replacing canals early on and docks later. But railways too declined steeply as lorry transport displaced 


\section{Table 1 Neighbourhood upgrading in seven cities}

Leipzig -Selective demolition of derelict blocks

-Restoration of pre-WW1 residential blocks

-Creation of small temporary green spaces awaiting redevelopment

-Investment in energy efficient upgrading of outer estates

Lille -Comprehensive improvements to poorer social housing areas, involving selective demolition, environmental improvements, new social facilities

Saint-Étienne -Major refurbishment of two poorest, most run down inner neighbourhoods

-Major investment in biggest, most problematic outer estates

Torino -Special "Projetto special perifeire" organised by city, supported by EU, targeting help at poorest neighbourhoods - significant resident involvement

-Upgrading of disused factory housing

Bilbao -Big reinvestment in oldest city centre neighbourhoods following severe floods in 1980s - some demolition of worst blocks

-Dense new building around periphery as population expands

Sheffield -Demolition of several large, poorly managed council-owned estates

-Slow upgrading of others - one area completely rebuilt

-Neighbourhood renewal in many older, inner-city terraced areas

Belfast -Terraced streets of inner city renewed or replaced

-Estates of public housing received significant investment, both for upgrading and new facilities

-Residents play very significant role

Source: Author's city visits

\section{Table 2 Examples of reuse of old and industrial buildings in the seven cities}

Leipzig -Conversion of old workshops and shop-fronts into new alternative enterprises

-Conversion of central station into covered shopping mall

Lille - Conversion of old railway station into a conference, meeting and events venue, plus restaurant and outdoor space for further activity Saint Sauveur

Saint-Étienne -Conversion of abandoned pit head, mining buildings and mine into a museum to recreate industrial history

-Restoration and conversion of Imperial Arms Factory into new Design Centre and incubator space for design businesses

Torino - -Large, disused factory turned into supermarket for Slow Food products

Bilbao - Conversion of vast wine warehouse in city centre into multi-use public and leisure venue - Alhondiga

-Conversion of nineteenth century machine engineering factory into incubator, start-up and SME work space

-Use of old industrial warehouse in the port area to develop Bilbao's home-bred Maker Movement

Sheffield -Conversion of Park Hill mass housing estate into a mixed income, high quality, council-built flat complex for social and private residents

-Conversion of old vestry building in Burngreave into community learning centre

-Conversion of abandoned Co-op store in city centre into a government-backed Fab Lab

Belfast -Conversion of old Custom buildings in Belfast dock into exhibition, event and visitors centre - Titanic Centre

-Conversion of old bank in Cathedral Quarter into 5-star hotel

-Upgrading and preservation of Crumlin Road jail into museum and visitor attraction

Source: City visits 2006-2014

them and industry vanished. Leipzig was left with the widest transcontinental array of railway lines in Europe, connecting East and West, linking most European countries across its centre (European Union, 2000). By the early 1990s, this railway hub had shrunk significantly; the same was true of Torino and Lille, as they too were the international connectors across Europe (Herden and Power, 2016; Power, 2016; Provan, 2016). Yet European cities are too dense, too close together, and too land-constrained to survive without recovering such immense and now under-used assets.

Greening the city-remediation at scale. Transforming this hydraheaded industrial legacy to beneficial use presented unprecedented challenges. Firstly, cities with government backing had to 
clean up the pollution in order to start rebuilding their economies, creating whole new industries specialising in environmental reclamation, particularly soil and industrial infrastructure (Urban Task Force, 1999). Secondly, their industrial architecture gained status as urban designers recognised a certain grandeur in these heavily built imposing structures. As buildings were scrubbed clean of soot, many original decorative features in the brick, wood, iron and stone work became visible. New uses crowded into these huge, disused shells: avant-garde flats; enterprise centres; business hubs; incubators for start-ups; new industrial clusters often linked to universities. This creative reuse of industrial buildings was widespread: Torino converted the giant abandoned Fiat factory buildings to house a huge conference venue and the engineering department of the Politecnico de Torino; other buildings became university-led incubators for start-ups, laboratories, research and exhibition centres. Leipzig and Lille both converted giant textile factory complexes into a high-tech hub in Lille, Euratechnologie and a creative design hub, the Spinnerai, in Leipzig (City Reports, 2007-2016). Torino converted disused railway repair sheds to mount the national exhibition marking the founding of Italy 150 years ago.

Thirdly, the clean-up of waterways not only opened the door to attractive residential developments along old quay sides, it also brought warehouses, factories and former dock buildings into use, linked to urban tourism. In Belfast, the Harland and Wolff ship building docks were converted into an industrial science park as well as a major tourist attraction, building on the famous Titanic which was built and launched in Belfast docks (Titanic Quarter, 2017).

Fourthly, detoxifying air, land and water brought greenery back into soot-blackened cities. Trees helped environmental recovery. Sheffield is now one of the most tree-clad cities in Europe, but is caught up in a fierce dispute over felling mature trees (Grubb et al. 2016). Leipzig, when it reclaimed the polluted site of its open-cast lignite mining, created a string of lakes in the denuded and poisoned landscape and forested it with trees after decontaminating it (Herden and Power, 2016).

All major industrial cities as they grew had created public parks in their centres to provide "lungs" for the dense population. These public parks had deteriorated and in some cases even fallen into disuse. Greening the cities attracted investment for restoring parks to their former glory. Lille's citadel, the central area of the city, built in Napoleonic times as a military fortress, became a majestic park, first restored after the First World War, and again after the Second World War (Kuklowsky and Provan, 2011). It now boasts urban cycle routes. Belfast is turning a huge landfill site on the North Foreshore of the city into the biggest park in the city region. Leipzig has converted its many demolition areas into parks and restored its canal sides with allotments and cycle ways.

Fifthly, cities needed their civic centres to be restored as the new magnet for growth. City centre restoration was possibly the strongest emblem of change. The town halls of these cities had been built in the hey-day of wealth creation. They outshone banks, schools, and universities in their grandeur and scale. Restored, they signalled a new confidence and attracted young talent into vital leadership jobs. Similar transformations took place with theatres, concert halls, swimming pools, and central libraries. When this reinvestment is linked to restored squares, pedestrian streets, renewed railway station links, and better housing, ex-industrial cities seem on a new trajectory. City centre restoration proved vital in underpinning recovery, attracting new talent and retaining skilled workers in the new jobs.

Finally, central railway hubs were restored and in several cities (Lille, Saint-Étienne, Leipzig, Torino and in planning Bilbao) connected internationally to high speed rail. Urban transport systems more broadly were transformed: creating large car-free squares and streets in historic centres; reinstating trams and improving buses with priority bus lanes; making large areas of cities cycle and pedestrian friendly; freeing up the streets for shops, cafes and small enterprises. Every city in our study set up bike hire schemes for very low cost or free for users.

The outcome of these transformative investments was to create more work, new skills, innovative workplaces and new opportunities in attractively restored cities. The recovered environments aided the growth in highly advanced industries that required space and a secure environment in which to experiment. Many new industries grew on the back of re-use.

The new economy and the growth of small and medium enterprises (SMEs). Thirdly, we explore the role of SMEs in driving city recovery and job growth. For some time after the closure of major industries in the cities, it was not clear what kind of economy would survive or re-emerge. But large-scale government investment in reclamation and restoration created many new jobs, some of them lasting years, providing new openings for younger workers who could no longer find industrial apprenticeships. New small businesses emerged around restoration, decontamination, remodelling and reuse, retail and hospitality. These same skills contributed to neighbourhood renewal and enterprise creation. Alongside this, restored infrastructure led to a growth in the arts, culture, education, commerce and finance, mostly through SMEs.

Some new services formed as breakaways from the unwieldy industrial structures that had gone before. Many of the reclaimed buildings became enterprise start-up centres for small, new businesses or innovation hubs for young entrepreneurs. The seven cities invariably provided support as well as space at low cost (Provan, 2016; Grubb et al. 2016a; Herden and Power, 2016).

European Regional Development Funds supported this process of conversion. They created special funds particularly for former industrial regions. Funding favoured regions of conflict resulting from economic decline (Dodd et al. 2013; Gobierno Vasco, 2012; UK Government, 2017). As a result, all the cities covered in this research received European investments that facilitated economic change (Power et al. 2008).

European Regional Development funds, matched by national and regional governments, led to an even stronger focus on new skills, local job recruitment, and community investment. Inevitably, given the ground breaking research and development that went into the new economy, many enterprises were small or medium sized-very few had above 200 workers and most had under 10 (Federation of Small Businesses, 2017). European Regional Development Funds also targeted energy saving in buildings, green infrastructure, decontamination and clean energy (European Commission, 2015). All these generated many small new enterprises.

Regional development plans for economic growth encouraged the creation of clusters and new business parks, often on the outskirts of the city, fostering networks of small enterprises trying to establish a foothold in the new economy. The Zamudio Business Park outside Bilbao successfully hosts a large cluster of environmental businesses (Power, 2016b). Saint-Étienne developed a cluster of environmental companies based on their growing skills in decontamination and greening the city (Provan, 2016a). The Advanced Manufacturing Park in Sheffield was set up through a partnership between Sheffield University's Advanced Manufacturing Research Centre, the City Council, and major international companies like Siemens, with Objective 1 funding from the European Union. It has attracted many innovative start-up SMEs (Sheffield Innovation Centre, 2017). The Science Park in the Titanic Quarter of Belfast is now 
producing blades for off-shore and on-shore wind turbines. Northern Ireland is set to become one of Europe's largest generators of off-shore wind (Grubb et al. 2016a). The restored Fiat factory at Mirafiore in Torino provides incubator space and training facilities for the young engineers and entrepreneurs emerging from the Politecnico (Power, 2016a). All of these examples suggest a new economic dynamism, fostered and directly supported by regional, national and European government funds.

Community enterprise. European social programmes were linked to the core idea of creating a springboard for local economic development (Winkler, 2007a; Provan, 2016a; Power, 2016a). They encouraged the integration of minorities and the recovery of marginalised, left-behind areas through housing renovation; developing community hubs offering work spaces, community facilities, advice and training; contributing funds to children's and youth programmes; and encouraging residents to do the jobs attached to these community projects.

Many of the locally based, community-oriented programmes led to community enterprises which offered training opportunities to residents, creating a chain effect-investment generates new jobs; new enterprises develop business skills; upgrading neighbourhood services expands the local economy; drawing isolated communities into more mainstream activity helps marginal households gain self-sufficiency. East Leipzig hosts a job shop where residents can drop in, get advice, learn about job openings and get help with applying for them (Herden and Power, 2016). In Torino, a community advice centre developed a bread-making co-operative run by Moroccan women immigrants (Winkler, 2007b). This took off as a viable community business in the home of Slow Food (Petrini, 2010). The number of jobs created through each initiative is small, but the cumulative impact is significant (European Commission, 2007; City Reports, 2007-2016).

Universities, advanced manufacture, innovation. Universities in industrial cities were founded and expanded to meet the demand for technical and engineering skills in industry. They have long focused their research and development on applied subjects, using engineering and scientific knowledge to develop new ideas, skills, and products. In former industrial cities, they have contributed to the new economy with high-tech, high skill, specialist incubators, based on their technical and engineering traditions. Old industrial specialisms such as textiles, steel, shipbuilding, and engines became foundation stones for advanced manufacture. New materials, advanced metals, high tech machinery, plastics, optics, industrial design, and the use of new methods transformed the nature of industrial production including its energy and materials use. This specialist research-based, high-skill economy built on the historic skill base in local industries. The training and research capacity of local universities strengthened emerging enterprises (Sheffield City Region, 2017).

The University of Sheffield illustrates this pattern. It has become the international research centre for the development of wind technology, deriving directly from Sheffield's historic expertise in advanced steel, blades and knives. The same applies to laser technology, high precision steel and cutting machinery, all of which are specialised modern products of Sheffield's steel history (Sheffield City Region, 2014). The combination of highlevel research and direct partnership with innovative industries has attracted some of the most recognised and specialised engineering companies in the world, Siemens, Boeing, and RollsRoyce among others (Grubb et al. 2016). The economic potential of Sheffield's historic expertise in steel, engineering, engine production and design, blade technology and high precision cutting is evidenced by the new small enterprises clustering in the Advanced Manufacturing Park (AMP) alongside very big names. The AMP is so successful that it is now being extended to a second nearby site. The Park is located between Sheffield and Rotherham, giving some spill-over benefits to Rotherham, one of Sheffield's poorer metropolitan areas. It now has a growing industrial sector. Sheffield has moved from extraordinarily high unemployment in the early 1980 s to close to the national average today (NOMIS, 2016).

Saint-Étienne in south eastern France has become the international City of Design, based on its historic engineering and manufacturing design prowess, linked to armaments and transport. It has also created an internationally renowned optics centre derived from its traditional expertise in high-precision lenses for arms. Napoleon's ambitious armaments production was based there. Saint-Étienne hosts advanced learning centres-"Écoles Supérieures"-in design, engineering and mining. The city was so contaminated by its coal and iron extraction and armaments industries that it has become expert in dealing with this problem, creating many new jobs in small and medium enterprises (Provan, 2016b).

Torino partnered with the regional government, the Politecnico University and Fiat, the giant carmaker headquartered in the city until 2015. This partnership used original Fiat buildings to develop leading research and business centres, coupled with impressive social initiatives in obsolete worker housing blocks. A young cooperative took them over, retrofitted them to a high energy standard and set them up as a self-funding "social hotel", offering short-term accommodation to a mixture of business visitors, students, homeless families evicted by private landlords, and tourists. There are several of these self-funding "social hotels" in Torino, to address Torino's chronic homelessness (Winkler, 2007b; Power, 2016a).

Torino is also home to a small design engineering company, Pininfarina, which designed from start to finish an all-electric car share system for modern cities. This break-through invention has become the "Autolib" electric car-share scheme in Paris, named after the pioneering Vélibes bike hire scheme (Pininfarina, 2017). There is a clear connection between Torino's history in car manufacture, Pininfarina, and the environmental transformation of cities.

These examples illustrate the innovations, often driven by environmental and economic imperatives together, which place these cities ahead. Highly damaging and in the end selfdestructive industry is being replaced by a multiplication of low-visibility SMEs which were at first seen in several cities as too insignificant, too low investment, too low tech to grow into breakthrough enterprises and certainly too difficult to organise into a coherent economic strategy.

Today the survival, strength, creativity and flexibility of SMEs has made them a major economic force in cities that retained their core strengths in invention, manufacture, problem solving and niche production (The Economist, 2015). Most private sector jobs in ex-industrial cities are now in small and medium enterprises (see City Reports, 2007-2016). Fully 87\% of all private sector jobs in Sheffield are in SMEs (Sheffield City Region, 2017). The recovering economy of ex-industrial cities no longer relies on a few dominant employers but on multiple small employers.

Arguably, the concentration of manufacturing jobs in single enterprises was dangerously exposed through an overconcentration of productive power. The break up into more manageable structures was predictable (Jacobs, 1970). This move to smaller, more flexible, more innovation-oriented employment structures was inevitable, given the failures of over-sized. Jane 
Jacobs, the American urbanist, predicted this trend in her famous book The Economy of Cities (Jacobs, 1970).

Universities were among the first to recognise the potential of the shift to smaller enterprises and developed not only new research and business partnerships that embraced SMEs, but encouraged bright young graduates to carry their skills forward, helping SMEs expand using high-level talent (Sheffield City Region, 2017; Power, 2016a). These developments became a driver of city recovery.

Metropolitan areas-their decline or recovery. Our fourth question considers wider metropolitan areas surrounding core cities. In the late nineteenth century, industrial cities rapidly spread beyond their original administrative boundaries, following the growth of suburban trains, trams and buses. The high level of toxic pollution from industries, the intense over-crowding of inner slums, extreme poverty, and the spread of infectious diseases led to a growing exodus of better off residents to more suburban areas and a growing metropolis, serviced by mechanised transport.

Suburbs. Suburbs are more spacious, more affluent, and better maintained than older, more decayed inner areas that house concentrations of lower income, lower skilled workers. Schools generally perform better in these outer suburbs, encouraging further exodus and higher house prices, generating sprawl building.

The problems and divisions created by sprawl have driven core cities to work more and more closely with their metropolitan authorities to agree common planning policies. For not only has car use expanded, causing pollution and congestion, sprawl also undermines city cohesion by drawing out of the city more ambitious and more successful households, particularly families. In the end, suburban expansion of itself has become self-defeating as travel times grow causing health problems and loss of productivity. In addition, outer building greatly intensifies environmental and social problems (Urban Task Force, 1999; Power, 2016; IPCC, 2014).

Core cities have developed anti-sprawl strategies with their surrounding metropolitan authorities to reinforce core city regrowth; Saint-Étienne, Lille, Leipzig, Belfast, and Sheffield all have "compact city" agreements (City Reports, 2007-2016; Rogers and Power, 2000). Anti-sprawl controls limit the expansion of wider metropolitan areas at the expense of core cities (Core Cities Group, 2009). Core city services only survive if the city tax base is strong enough. If not, suburban residents lose the services they rely on and cities lose their viability, as has happened in some US cities (Katz and Bradley 2013; Mallach and Brachman, 2012). By strengthening the core city, which is in a natural leadership position within the metropolitan area, city regions gain jobs. Travel to work analysis shows that city jobs pull industrial workers from a wide metropolitan area (LSE Cities, 2017; Power, 2016).

Satellite towns. The spread of major industry led to the growth in satellite industrial towns around most major ex-industrial cities (LSE Cities, 2017).

These regional industrial towns became producers in their own right. The coal mining areas around Sheffield and Lille, and the industrial suburbs around Bilbao illustrate this (Power, 2016; Mondragon, 2017). Many of these towns declined rapidly and steeply as major industries collapsed. Barnsley, Doncaster and Rotherham in South Yorkshire, outside Sheffield, demonstrate that trajectory (Cabinet Office and Deputy Prime Ministers Office, 2014). So do Roubaix, Tourcoing, and Ville Nueve d'Ascq, outside Lille, Halle outside Leipzig, and Barracaldo outside Bilbao (Herden and Power, 2016; Provan, 2016; Power, 2016b). Satellite towns do not have the recovery potential of core cities because their economic rationale as primary producers did not support core city services such as universities, teaching, hospitals, and rail hubs. These anchor institutions thrive in major urban centres and provide a foundation on which to build a new economy. Peripheral industrial areas struggle to follow the same recovery trajectory.

The actions to help smaller, less significant industrial towns around the peripheries of core cities have been insufficient to help them recover in a similar way. The more purely industrial and mining areas that are separate from, but linked to, core cities have yet to find a recovery trajectory.

The polarisation that separates core city recovery from continuing peripheral struggles may be an over-simplification however. It is the core cities that experienced the most acute decline. They not only lost skilled workers and professionals to newer and more attractive suburbs; they retained a large redundant, de-skilled and often alienated workforce - a hard core of often bitter ex-manual workers (Power and Mumford, 1999). Left-behind workers share space with large minority communities who were drawn to the inner city, often in the later phases of industrial growth, to perform the jobs increasingly rejected by a highly paid, mostly unionised workforce: Southern Italians and later Africans in Torino; Southern Spaniards in Bilbao; Somali and Yemeni populations in Sheffield; sub-Saharan Africans and Roma in Lille; North Africans in Saint-Étienne; East Europeans in Leipzig and Belfast (City Reports, 2007-2016). These minorities have often ended up populating the outer estates of subsidised housing, increasingly vacated by more economically active local populations.

As part of a recovery strategy, core city policy has focused on attracting back suburban dwellers and their offspring into the city, and attracting incomers with skills to fill new jobs in the new economy. Policies to support this ambition, such as neighbourhood renewal, have helped to boost city populations, sometimes at the direct expense of the suburbs. The anti-sprawl policies of Leipzig, Lille, Saint-Étienne, and Belfast illustrate this direction and other cities follow a similar if less clean cut line (Plöger, 2007b; Provan, 2016; Provan, 2016a). Major infrastructure investment and reclamation has been far more concentrated in core cities than wider metropolitan areas for this reason (Power, 2016).

Regional government. However, regional government can play an important and distinctive role. Some regions have a strong history of autonomy and leadership. For example Piedmont, of which Torino is the regional capital, was historically a prosperous, independent state in its own right. It actively promotes regional strengths as part of, and in support of, the recovery of Torino. Several key industries have survived and grown in the outer metropolitan areas of Torino. The region of Piedmont has been an invaluable partner in Torino's new economy (Power, 2016a).

The Basque region around Bilbao also has a long history of regional autonomy, albeit frequently undermined by central government, particularly under Franco's dictatorship. The region provides resource underpinning the core city of Bilbao, and without significant regional autonomy and backing, Bilbao would not have recovered so successfully (Plöger, 2007c; Power, 2016b). Lille Metropole, the government of the city-region around Lille, which is at its core, is leading on a plan to make the whole region carbon neutral over 30 years (Provan, 2016; Rifkin, 2014). This plan, adopted by Lille Metropole and the wider region of Pas de Calais, fits closely within our proposed framework. The devolution of power and resources to city regions creates momentum 


\section{Unsustainable Economy - over-use}

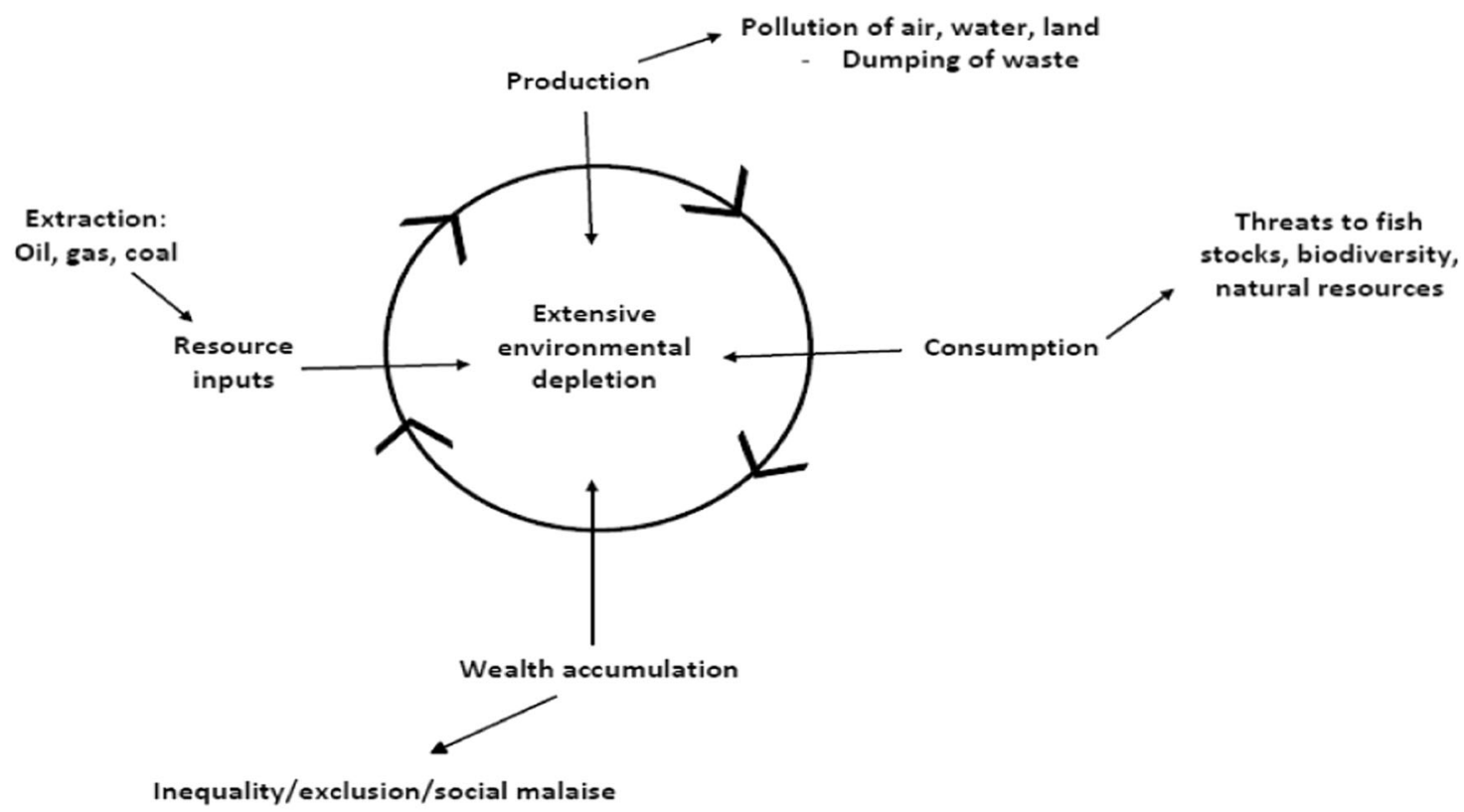

\section{Sustainable Economy - closed loop}

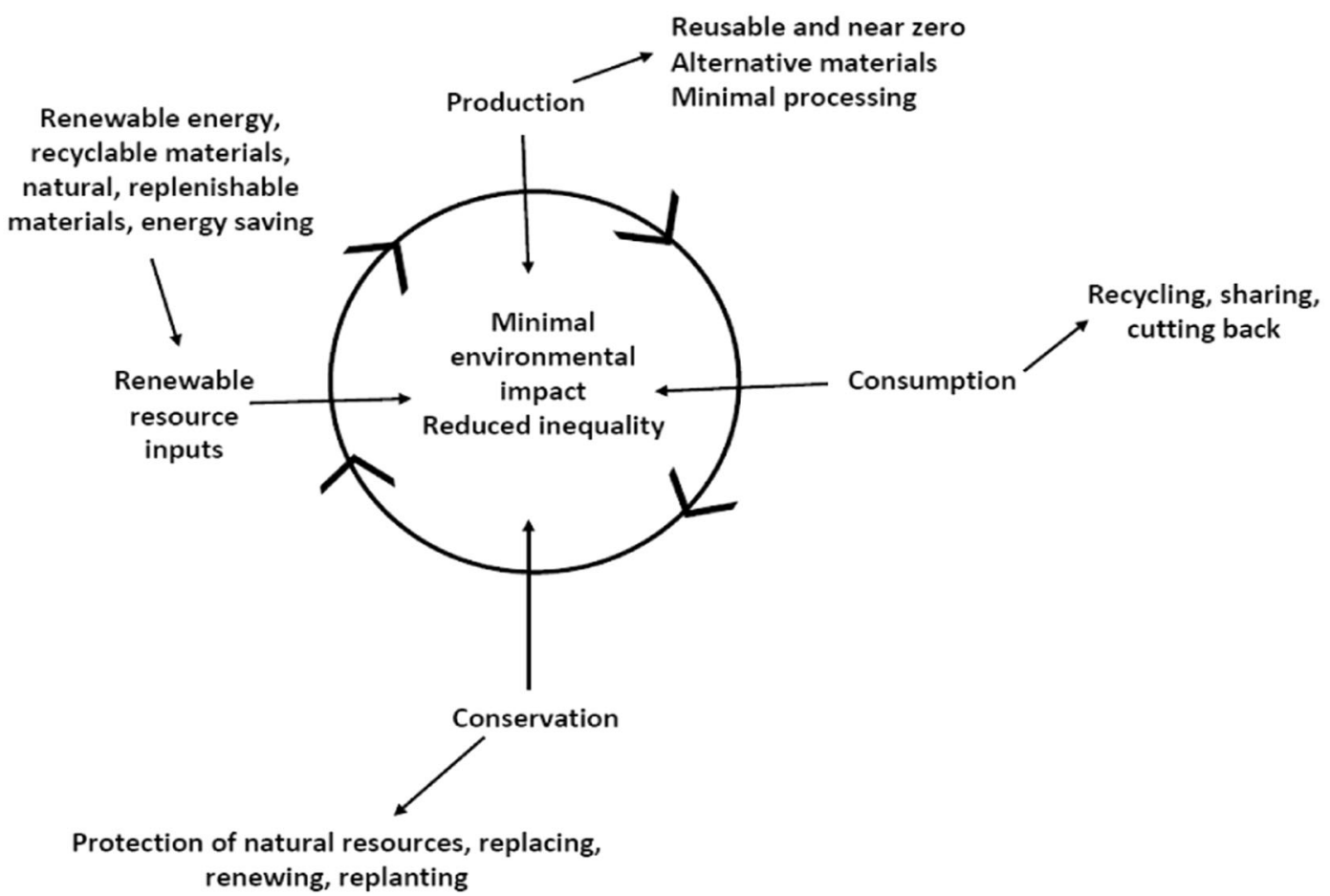

Fig. 3 Diagrammatic representation of an unsustainable economy and a sustainable economy, based on an article by William Rees in Sustainable Cities, edited by David Satterthwaite

towards such ambitious goals. Many new jobs lie at the heart of the Lille Metropolitan/Pas de Calais plan. It could offer a breakthrough model for the new, resource-constrained economy.

Metropolitan areas may over time become stronger on the back of urban recovery, since the periphery offers space and capacity for further growth as city success creates new pressures. There are some signs that regional devolution aids growth as cities rely on the wider metropolitan area for regrowth, as Zamudio Business Park outside Bilbao, and the Advanced Manufacturing Park outside Sheffield illustrate (Power, 2016; Grubb et al. 2016). The interdependence of city and metropolitan area aids the recovery of both, as population and employment statistics show (Power, 2016).

Needs must-environmental limits and the Re-economy. Our fifth question is whether the regrowth of cities is strong enough to sustain progress and development in an environmentally sustainable way. 
Europe's industrial regions are simply too big and too populous, land in Europe is too constrained, and regional ties too strong, to allow the abandonment of urban communities on a scale comparable to America's rustbelt. The European response therefore is to try and make good what is damaged. The obvious, practical option for a lived-in and struggling city in a crowded continent is to build a Re-economy: restore and rebuild, reuse existing infrastructure, revalue local skills, redirect historic talents for invention and innovation, reorient the economy. The redirection of ex-industrial cities towards a Re-economy involves lower carbon, less energy, lower materials throughout, less waste, and a less "locked-in" economic system as Nicholas Stern argues. The Paris Climate Change Agreement of 2015 commits us to this path if we are to avoid dangerous climate change. Europe is particularly at risk because of its dense population and high level of concentrated development (Stern, 2015; UN, 2015).

Our model of city regrowth points towards putting back what we take out and reusing what we already have, which we must do if the planet is to survive. The ex-industrial cities we have studied contain so much infrastructure, so many buildings, so many undervalued neighbourhoods, so many cultural and educational assets, and so many people with latent talents and skills that they are creating a new economy, which we call the Re-economy, building on what is there already. This is how cities renew themselves again and again, like the ancient Phoenix (Power et al. 2010).

Figure 3 illustrates the unsustainable economy of extraction and mass production, which has failed, and the sustainable circular economy of regrowth, based on what can be recycled. These cities need to remake themselves constantly. Though the legacy of damage is devastating, there is also the legacy of talent and inventiveness that can be used in a new "circular economy". Core cities are experimenting with this idea.

City recovery may prove strong, inventive and constrained enough in its resource use to become practically sustainable. There is little alternative. The shift to renewable energy in all the cities, the reuse of existing materials, infrastructure, buildings, and the reduced consumption of energy-intensive materials all point towards a more circular and therefore more sustainable economy.

The role of government in reorienting city fortunes. Our sixth question addresses the role of city leaders in aiding city recovery.

Core cities flourished on concentrated industrial growth. Often, they grew around historic pre-industrial functions. They created the major institutions that generated constant technical innovations, displaying brilliant industrial prowess, particularly in universities, technical colleges, teaching and research hospitals. Some had ancient universities that expanded into the industrial age, for example Torino, Leipzig, and Lille. Some built great engineering and technical universities, such as Sheffield, Bilbao and Saint-Étienne, that became the centres of the first, second and third industrial revolutions (Rifkin, 2011). Their cultural assets were also monumental. The Bach Choir still sings in the Thomaskirche in Leipzig, where J.S. Bach was organist in 1723-1750 (Plöger, 2007b).

Industrial cities gained immense power and prestige, because of their core producer role. Local governments were invented in them and became central to making them healthier-through sanitation, clean water, street paving and lighting (Power and Houghton, 2007). Local governments, often representing local business interests, cared for their cities, made them more attractive to incomers, endowed them with features that make cities great such as imposing town halls, concert venues, orchestras, choirs, libraries, public parks, public baths, hospitals, and schools (Briggs, 1968; Hunt, 2005). With such legacies, civic leaders became determined to battle through the collapse of industry.

It took a decade or two of steep decline for civic leaders to recognise that a new approach was needed. In all seven cities, key figures emerged who facilitated the recovery process. In some cases, notably Sheffield and Belfast, it was leading city officials who facilitated a change of direction. In most European cities, it was elected mayors with considerable powers who drove the changes. In at least three cities, Lille, Bilbao and Torino, regional governments backed city leaders and oriented regional economic decisions in their favour - for example fast transport links to bigger centres. Other city regions with less devolution of powers such as Sheffield, Belfast and Saint-Étienne are later in the process.

In several ways city governments have led the reshaping of their cities:

- First, they are the brokers and conduits for regional, national and EU funding. They had to win the support of surrounding metropolitan areas to achieve this.

- Second, they brokered new relations with the private sector to attract inward investors and support their local small enterprise sector. They became business-friendly in new ways.

- Third, they had to win the support of the local electorate if they were to have sufficient mandate to reorient the city. This involved reaching out to all sections of the community, from the university educated to low skilled manual workers.

The methods differed, but the processes of involvement shared some common characteristics between all the cities: neighbourhood reinvestment with a high involvement of residents; the creation of attractive public spaces and pedestrianised areas; the restoration or creation of local green spaces, play areas and parks; investment in flagship public amenities such as new concert halls, exhibition centres, sports arenas, neighbourhood centres; a traffic calming and public transport orientation that brings the city together; the creation of public-private partnerships with support from the private sector.

City governments also play a leading role in skills programmes, although France stands out as having a highly centralised job training and educational system. Maybe most significant of all is the role of city governments in environmental reclamation and innovation, often through arm's length and partnership-based bodies.

The recovery process created a new level of commitment, skill and imagination in tired town halls. Citizens who had previously taken too much for granted, and skilled incomers, attracted by the economic and social potential of so many empty spaces, were encouraged to participate. This did not stop the very poorest, most run down areas of Saint-Étienne, Leipzig and Bilbao displaying protest posters against "gentrifiers". But "Urban Pioneers", proved invaluable as they reclaimed and reoccupied abandoned spaces. Cities that had lost so much population and enterprise needed to revitalise urban spaces and populations (Rogers and Power, 2000).

Overall, city governments led the reconfiguring of their cities, rebuilding of their economies and reclaiming of their environments. They have succeeded in focussing the attention of their city regions, wider metropolitan areas and national governments on the core city. They are leading this transformation.

\section{Concluding thoughts}

The seven case studies in this paper were chosen from several similar cities in each country on the basis that they were reflective of a wider trend. The population and job losses were significant in 
each city and yet they are now all recovering population and employment rates have moved back towards national averages. New city leadership has generated a new economy based on high engineering and technical skills, even though manufacturing and manual jobs have generally continued to decline. Universities are playing a critical role in this, as are small and medium enterprises. External investment and government support has been crucial.

The programmes and investments that helped these seven cities recover were applied to many other cities suffering big industrial losses, using the same rationale and with similar impact. The combination of elements and actions in each city varied somewhat but the pattern of change was common, as the most recent Urban Audit shows (European Commission 2017).

Progress is tangible. Many developments in renewable energy and environmental protection have taken shape over the ten years of recovery. The upgrading of housing and neighbourhoods has attracted new blood into the cities and into the poorest neighbourhoods. These cities weathered the 2008 crisis far better than the financial centres that were, and still are, much richer.

It is unclear how far the recovery process will grow, but climate change pressures are becoming serious and cities working under severe resource constraints are better placed to develop a new economy, more suited to the limits of the future, than cities that are still extravagant in their use of resources. For this reason, we argue that a new kind of economy, a Re-economy, where everything reshapes and renews itself rather than starts afresh, is taking root. Our evidence shows that a patchwork of solutions creates a clear pattern of renewal as we have found in these cities. Evidence suggests that this is happening across Europe, and to some extent in the United States, Canada and other developed and developing cities (United Nations, 2016; Angel, 2012).

Received: 30 June 2017 Accepted: 30 April 2018

Published online: 07 August 2018

\section{References}

Angel S (2012) Planet of Cities. Cambridge, MA: Lincoln Institute of Land Policy Briggs A (1968) Victorian cities. Penguin Books, Harmondsworth

Briggs A (1983) A social history of England. Book Club Associates, London

Cabinet Office and Deputy Prime Ministers Office (2014) Made in Sheffield-A deal for Growth. City Deal for Sheffield. https://www.gov.uk/government/ publications/sheffield-cityregion-growth-deal

Cantle T (2001) Community cohesion: a report of the independent review team. Community Cohesion Review Team. Home Office, London

Core Cities Group (2009) Core Cities: Delivering Employment and Skills. CoreCities Group and Improvement and Development Agency for Local Government. https://www.corecities.com/sites/default/files/field/attachment/ corecitiesskillsandemployment.pdf

City Reformers Group (2006) Take away findings. LSE Housing and Communities, CASE, London, 2012

Danube Regional Project (2001) Strengthening the Implementation Capacities for Nutrient Reduction and Transboundary Cooperation in the Danube River Basin. UNDP. http://www.undp-drp.org/drp/danube.html

Dodd J, Fox T, Gunther S, Tosics I (2013) Housing investments supported by the European Regional Development Fund 2007-2013. European Commission, Brussels

The Economist (2017, April 15) East Germany's Population is Shrinking. http:// www.economist.com/news/finance-and-economics/21720578-rest-countryand-large-swathes-europe-will-face-similar-problems

The Economist (2017, December 19) Whither Nationalism? https://www. economist.com/news/christmas-specials/21732704-nationalism-not-fadingaway-it-not-clear-where-it-heading-whither

The Economist (2015, January 29) The Great Incubator. http://www.economist. com/news/britain/21641266-makers-are-thriving-capitalbut-perhaps-notlong-great-incubator

EIM Business \& Policy Research (2011) Do SMEs Create More and Better Jobs? European Commission, Brussels
El Pais (2017, April 21) "La 'banlieue' que es vivero de estrellas y de yihadistas" http://internacional.elpais.com/internacional/2017/04/20/actualidad/ 1492715902_079922.html

European Union (2000) Europe-wide Rail Network Exhibition at the Millennium Dome

Eurostat (2013) Focus on European cities. European Commission, Brussels

Eurostat (2017) European Statistics Explained. Including Urban Audit statistics. http://ec.europa.eu/eurostat/statistics-explained/index.php/ Statistics_on_European_cities

European Commission: DG Regional Policy (2007) State of European cities. EC, Brussels

European Commission (2015) European Regional Development Fund. http://ec. europea.eu/regional_policy/en/funding/erdf

European Commission (2007-2016) Urban Audit. European Commission Regional Policy. development/audit/

European Community (1957) Treaty of Rome, European Union, Treaty Establishing the European Community (Consolidated Version). www.refworld.org/ docid/3ae6b39c0.html

Fabrique de la Cité (2013) Recovering Cities: How to create value for cities? Experience of seven "Phoenix Cities". Presentation from Fabrique de la Cité's Stockholm Seminar, 17 Oct 2013

Fabrique de la Cité (2015) Lille Workshop

Federation of Small Businesses (2017) UK Small Business Statistics: Business population estimates for the UK and regions, 2016. https://www.fsb.org.uk/ media-centre/small-business-statistics

Gobierno Vasco. (2012). 25 Anos de Euskadi en Europa: La ayuda a Euskadi de los fondos estructurales europeos 1986-2011. Departamento de Economia y Hacienda. http://repositori.uji.es/xmlui/bitstream/handle/10234/52580/25anos-de-Euskadi-en-Europa.pdf?sequence $=1$ \&isAllowed $=\mathrm{y}$

Goodwin MJ, Heath O (2016) The 2016 Referendum, Brexit and the Left Behind: An aggregate-level analysis of the result. Joseph Rowntree Foundation. https://www.jrf.org.uk/report/brexit-vote-explained-poverty-low-skills-andlack-opportunities

Greater Manchester Combined Authority (2012) Greater Manchester City Deal. Cabinet Office and Deputy Prime Minister's Office, London

Greater Manchester Health and Social Care (2017) Taking Care of Social Care and Health. Greater Manchester Combined Authority. http://www.gmhsc.org.uk/

Grubb B, Lane L, Power A (2016) Sheffield City Report. CASEReport 103. LSE Housing and Communities, London

Grubb B, Lane L, Power A (2016a) Belfast City Report. CASEReport 102.LSE Housing and Communities, London

The Guardian (2014, June 17) Racism in Northern Ireland: Up to three race-related incidents reported daily. https://www.theguardian.com/uk-news/2014/jun/17/ racism-northern-ireland-race-related-incidents-reported-daily

Halsey AH (1988) British Social Trends Since 1900: a guide to the changing social structure of Britain. Macmillan, Basingstoke

Herden E, Power A (2016) Leipzig City Report. CASEReport 107. London; LSE Housing and Communities

HM Government (2011) Unlocking Growth in Cities: City deals wave 1. https:// www.gov.uk/government/uploads/system/uploads/attachment_data/file/ 7523/CO_Unlocking_20GrowthCities_acc.pdf

HM Government (1956) Clean Air Act

Houghton J, Power A (2007) Jigsaw Cities: Big places, small spaces. Policy Press, Bristol

Hunt T (2005) Building Jerusalem: The rise and fall of the Victorian city. Phoenix, London

European Commission (2017) European Regional Development Fund. http://ec. europa.eu/regional_policy/en/funding/erdf/

INSEE Rhone Alpes (2013) Pôle urbain de Saint-Étienne Analyses No 209 Novembre. INSEE, Lyon, Lyon, p 2013

Intergovernmental Panel on Climate Change (2014) Climate Change 2014: Impacts, Adaption and Vulnerability. http://www.ipcc.ch/report/ar5/wg2/

Jacobs J (1970) The Economy of Cities. Random House, New York

Katz B, Bradley J (2013) The Metropolitan Revolution: How cities and metros are fixing our broken politics and fragile economy. Brookings Institution Press, Washington

Katz B, Jones A (2016) "Shoots of Growth in Older Industrial Cities in the UK" in Power, A. Cities for a Small Continent: International Handbook of City Recovery. Policy Press, Bristol

Kuklowsky C, Provan B (2011). Report to Plan Urbanisme Construction Architecture on progress in France's former industrial cities. CASE Report 70. London: Centre for Analysis of Social Exclusion

Lane L, Plöger J, Power A, Winkler A (2009) Tale of Seven Cities. A practitioner's guide to city recovery. Centre for the Analysis of Social Exclusion, London

LSE Cities (2017) European Metromonitor: Cities and economic recession since 2008. http://labs.lsecities.net/eumm/home/ 
Mallach A, Brachman L (2012) Rebuilding America's Legacy Cities: New directions for the industrial heartland. Columbia University: The American Assembly. http://americanassembly.org/publications/rebuilding-americas-legacy-citiesnew-directions-industrial-heartland

Mondragon (2017) Our history. http://www.mondragon-corporation.com/en/cooperative-experience/history/

Mumford K, Power A (2003) Boom or Abandonment: resolving housing conflicts in cities. Chartered Institute of Housing, Coventry, UK

NOMIS (2016) Labour Market Profile-Sheffield City Region. https://www. nomisweb.co.uk/reports/lmp/lep/1925185559/report.aspx

Office of the Deputy Prime Minister (2003) Sustainable Communities: Building for the Future. http://webarchive.nationalarchives.gov.uk/20060502043818/ http://odpm.gov.uk/pub/872/

SustainableCommunitiesBuildingfortheFutureMaindocumentPDF2121Kb_id1139872.pdf

Office of National Statistics (ONS) (2016) Annual Population Survey. https://www. nomisweb.co.uk/query/select/getdatasetbytheme.asp?theme $=28$

Oval and Kennington Development Area (2015) Gas holder document. Berkeley Group and London Borough of Lambeth Council, London

Osbourne G (2014) Chancellor: 'We need a Northern powerhouse'. Speech at the Museum of Science and Industry, Manchester, https://www.gov.uk/ government/speeches/chancellor-we-need-a-northern-powerhouse

Parkinson M et al. (2006) State of the English cities: a research study. Office of the Deputy Prime Minister, London

Petrini C (2010) Terra Madre: Forging a new global network of sustainable food communities. Chelsea Green Publishing Company, White River Junction

Pininfarina (2017) Pininfarina Bluecar: http://www.pininfarina.com/en/ pininfarina bluecar/

Plöger J (2007a) Bremen City Report. CASEReport 39. LSE Housing and Communities, London

Plöger J (2007b) Leipzig City Report. CASEReport 42. LSE Housing and Communities, London

Plöger J (2007c) Bilbao City Report. CASEReport 43. LSE Housing and Communities, London

Plöger J (2007d) Belfast City Report. CASEReport 44. LSE Housing and Communities, London

Power A (1999) Estates on the Edge: The social consequences of mass housing in Northern Europe. St Martin's Press, New York

Power A (2016) Cities for a Small Continent: International Handbook of City Recovery. Policy Press, Bristol

Power A (2016a) Torino City Report. CASEReport 106. LSE Housing and Communities, London

Power A (2016b) Bilbao City Report. CASEReport 108. LSE Housing and Communities, London

Power A, Mumford K (1999) The Slow Death of GreatCities: Urban Abandonment or Urban Renaissance. Joseph Rowntree Foundation, York

Power A, Plöger J, Winkler A (2008) Transforming Cities AcrossEurope: An interim report on problems and progress. CASEReport49. LSE Housing and Communities, London

Power A, Plöger J, Winkler A (2010) Phoenix cities: The fall and rise of great industrial cities. Policy Press, Bristol

Power A, Tunstall R (1997) Dangerous disorder: riots and violent disorder in thirteen areas of Britain 1991-1992. Joseph Rowntree Foundation, York

Power A, Richardson L, Seshimo K, Firth K, Rode P, Whitehead C (2004) A Framework for Housing in the London Thames Gateway. CASEBrief 27. LSE Housing and Communities and Enterprise LSE Cities, London

Provan B (2016) Lille City Report. CASEReport 104. LSE Housing and Communities, London

Provan B (2016a) Saint-Étienne City Report. CASEReport 105. LSE Housing and Communities, London

Rogers R, Power A (2000) Cities for a Small Country. Faber and Faber, London

Rifkin J (2011) The Third Industrial Revolution: how lateral power is transforming energy, the economy and the world. Palgrave Macmillan, New York

Rifkin J (2014) The Zero Marginal Cost Society. Palgrave Macmillan, New York

Sheffield City Region (2014) Bigger Economy, Better Business, FasterGrowth: Sheffield Economic Strategy. Welcome to Sheffield, Sheffield

Sheffield City Region (2017) RISE. Sheffield City Region, Sheffield

Stern N (2015) Why Are We Waiting? The logic, urgency and promise of tackling climate change. MIT Press, Cambridge, Massachusetts

The University of Sheffield Innovation Centre (2017) 'About Us'. The University of Sheffield, Sheffield

Times Books (1990) The Times Atlas of the World. Times Books, London

Urban Task Force (1999) Towards an Urban Renaissance. Urban Task Force and Department of the Environment, Transport and the Regions, London
Thiolliere M (2007) Quelle Ville Voulons-nous? Acteurs de la société, Paris The UK in a Changing Europe (2017) http://ukandeu.ac.uk/

Titanic Quarter (2017) Titanic Quarter a Key Contributor to Northern Ireland's Economic Growth. Blog Post, 1 June 2017. http://titanic-quarter.com/blogs/ 24/TITANIC-QUARTER-A-KEY-CONTRIBUTOR-TO-NORTHERNIRELANDS-ECONOMIC-GROWTH

UK Government (2017) 2007 to 2013 ERDF programmes: achievements. https:// www.gov.uk/guidance/erdf-programmes-progress-and-achievements

United Nations (2015) Framework Convention on Climate Change: Adoption of the Paris Agreement. United Nations, Paris

United Nations (2016) The World's Cities in 2016: Data Booklet. http://www.un. org/en/development/desa/population/publications/pdf/urbanization/ the_worlds_cities_in_2016_data_booklet.pdf

Walgate, Robert (1983) Acid Rain Research: Too late for the Black Forest? Nature 303, Issue 743

Weak Market Cities Group (2007) Leipzig Workshop

Wilson WJ (1987) The Truly Disadvantaged: The inner city, the underclass and public policy. University of Chicago Press, Chicago

Winkler A (2007a) Saint-Étienne City Report. CASEReport 40. LSE Housing and Communities, London

Winkler A (2007b) Torino City Report. CASEReport 41. LSE Housing and Communities, London

Winkler A (2007c) Sheffield City Report. CASEReport 45. LSE Housing and Communities, London

\section{Data availability}

Data sharing is not applicable to this article as no datasets were generated during the current study. All data analysed during this study are included in this published article or can be found within the references.

\section{Acknowledgements}

The author would like to thank leaders and practitioners in the seven case study cities, national and local government officials and experts in the five countries and seven cities, and the City Reformers Group that met regularly over ten years in London, Dortmund and Lille. I also want to thank officials in the European Commission, the Core Cities Group (UK), Fabrique de la Cité (Paris). Several individuals helped directly with the project, particularly Bruce Katz, formerly of the Brookings Institution, Massimo Bricocoli of the Politecnico de Milano, Jörg Plöger, and Astrid Winkler (formerly of LSE) and the authors of the City Reports published in 2016 at the London School of Economics, particularly Bert Provan, Laura Lane, Eileen Herden, and Ben Grubb. Finally, I would like to acknowledge the help of LSE Cities, with their constantly updated European City Monitor, the Urban Audit for including me in their Expert Advisory Panel for the latest report, and Policy Press for agreeing to my writing this article using material from two earlier books. I accept full responsibility for any errors.

\section{Additional information}

Competing interests: The author declare no competing interests.

Reprints and permission information is available online at http://www.nature.com/ reprints

Publisher's note: Springer Nature remains neutral with regard to jurisdictional claims in published maps and institutional affiliations.

pen Access This article is licensed under a Creative Commons Attribution 4.0 International License, which permits use, sharing, adaptation, distribution and reproduction in any medium or format, as long as you give appropriate credit to the original author(s) and the source, provide a link to the Creative Commons license, and indicate if changes were made. The images or other third party material in this article are included in the article's Creative Commons license, unless indicated otherwise in a credit line to the material. If material is not included in the article's Creative Commons license and your intended use is not permitted by statutory regulation or exceeds the permitted use, you will need to obtain permission directly from the copyright holder. To view a copy of this license, visit http://creativecommons.org/ licenses/by/4.0/.

(c) The Author(s) 2018 